\title{
Pharmaciana
}

Vol.11, No.2, July 2021, Page. 175-184

ISSN: 2088 4559; e-ISSN: 24770256

DOI: $10.12928 /$ pharmaciana.v11i2.20666

\section{Evaluation of glycemic index determination method}

\author{
Ratna Sari Listyaningrum, Didah Nur Faridah", \\ Puspo Edi Giriwono, Masayu Nur Ulfa \\ Department of Food Science and Technology, IPB University, \\ Campus IPB Dramaga, Bogor, West Java, Indonesia
}

\begin{abstract}
In Indonesia, determination of glycemic index (GI) was performed according to approved protocols prescribed by FAO (1998) and BPOM (2011); but, remarkable differences among these methods exist, primarily regarding the points of recommendation. This present work aimed to evaluate the technical steps of the protocol for determining GI between two protocols recommended by BPOM (2011) and FAO (1998). Ten healthy subjects (age 21-36 years old and body mass index (BMI) 18.5$24.9 \mathrm{~kg} / \mathrm{m}^{2}$ ) were recruited for the study. The blood glucose was measured with repeated glucose trials, while the number of sampling points for the blood glucose test was also investigated. The range of GI for rice, wheat cookies, NS-cookies, HMT-cookies were 68-77; 55-60; $35-43$; 35- 41, respectively, using the combination of three different aspects between FAO and BPOM protocol. Noticeably, the difference in glucose trials did not cause significant variations to GI $(n=10, p>0.05)$. Regarding statistical performance between methods, the Coefficient of Variance (CV) resulted from BPOM protocol (10 subjects, 5 sampling points) ranged 37 to $49 \%$, being slightly higher compared to CV obtained from FAO protocol ( 7 subjects with triplicate glucose trials, 7 sampling points), i.e., $33 \%$ and $35 \%$. The conclusive remark was noticed, that the most satisfying protocol for determination of GI was achieved using no less than two reference food trials, seven subjects, and seven blood sampling points.
\end{abstract}

Keywords: arrowroot, cookies, glycemic index

\footnotetext{
*Corresponding author:

Didah Nur Faridah

Department of Food Science and Technology, IPB University

Campus IPB Dramaga, Bogor, West Java, Indonesia

Email: didah_nf@apps.ipb.ac.id
} 


\section{INTRODUCTION}

The glycemic index (GI) concept can be used to assist in the selection of foods in a healthy diet. The GI value allows us to estimate the likely effects of food on blood glucose levels when consumed. Low-GI food tends to lower postprandial blood glucose and insulin response (Wolever et al., 1992). Based on FAO/WHO (1998), low-GI foods are highly recommended for management of diabetes and glucose intolerance-related disease, while they are also scientifically proven to give beneficial effects on human health (Barakatun Nisak et al., 2009; Bouché et al., 2002; Liu et al., 2000;Moses et al., 2009; Stevenson et al., 2006; Gilbertson et al. 2001; Wolever et al., 1991). For this reason, food processors make nutrient content claims regarding the GI of the food. Therefore, the determination of GI value should receive a serious consideration. According to National Agency of Drug and Food Control or in Indonesian it called Badan Pengawas Obat dan Makanan (BPOM) (2011) and FAO/WHO (1998), the use of in vivo experiment with human as subject has been the most common method, consisting of some steps including preparation of ethical clearance, reference and samples, the selection of research subjects, blood sampling, analytical methods, and the calculation of GI. Nevertheless, the application of this method is hindered by its high cost; thus, there is a need to study the efficacy of the method. FAO/WHO recommends that the reference food test be repeated three times, while BPOM does not give any specific recommendations. In addition, blood glucose sampling points are carried out seven points, i.e. $0,15,30,45,60,90,120 \mathrm{~min}$ after reference, as recommended by $\mathrm{FAO} / \mathrm{WHO}$, being slightly higher compared to the recommendation of BPOM, i.e., 0, 30, 60, 90, 120 min after reference.

Reduction of GI can be attempted by several ways. Some studies indicate that food containing high resistant starch (RS) can decrease the estimated-GI (eGI) (Mir et al., 2013; Odenigbo et al., 2012). In addition, heat moisture treatment (HMT) on arrowroot starch at $121{ }^{\circ} \mathrm{C}$ with a moisture content of $20 \%$ for $15 \mathrm{~min}$ could increase RS content of arrowroot starch from $2.15 \%$ to $7.04 \%$ (Syahbanu, 2015). Another research showed that the application of HMT (30\% moisture content, $2 \mathrm{~h}$, $120{ }^{\circ} \mathrm{C}$ ) enabled to alleviation eGI of all gelatinized starches (Chung et al., 2009). The interactions between amyloses formed during HMT decreased enzymes hydrolyzation, thereby decreasing eGI. Arrowroot has been known to have a low GI value of 14, compared to yam (90), taro (95), edible canna (105), sweet potato (179) and suweg (42) (Faridah, 2005; Marsono, 2002). Therefore, cookies made from HMT-modified arrowroot starch possessed a lower value of GI, compared to cookies made from wheat, native arrowroot starch, and white rice. Thus, the objective of this study was to evaluate the technical steps of in vivo experiment with regard to the determination of GI of HMT-modified arrowroot cookies, which include subjects enrolled, glucose trials, and blood glucose sampling points.

\section{MATERIALS AND METHODS Materials}

This research used wheat (Tepung Segitiga Bogasari, Indonesia), native arrowroot starch (obtained from Kelompok Wanita Tani Yogyakarta, Indonesia), and HMT-modified arrowroot starch. Dextrose monohydrate/glucose (Qinhuangdao Lihua Starch CO, China) was used as reference food. Instruments used in this research were centrifuge (Eppendorf 5810R, Germany), spectrophotometer UVVIS (Shimadzu UVmini-1240, Japan), shaking water bath (Burgwedel GFL 1083, Germany), pH meter (Eutech pH700, Singapore), vacuum-system (B'u'chi B-169, Switzerland), and analytic scale (Precisa XT220A, Switzerland).

\section{Subject of the study}

The subjects used in this study were 10 subjects. Inclusion criteria in this research were healthy, range of age between 21-36 years old and range of normal body mass index (BMI) between 18.5-24.9 $\mathrm{kg} / \mathrm{m}^{2}$, while exclusion criteria were having a history of diabetes mellitus, pregnant, and having a smoking habit. BMI was calculated as weight $(\mathrm{kg})$ divided by height $\left(\mathrm{m}^{2}\right)$. All subjects were given 
informed consent to participate. Ethical clearance was obtained from the Ethics Committee, The Health Ministry of Indonesia (LB.02.01/5.2/KE.142/2014).

\section{Methods}

The research began by modifying arrowroot starch with HMT method, which was then used as a base for HMT cookies. There were also cookies from arrowroot starch without modification, cookies from wheat flour, and white rice. All samples were then proximate analysed. The portion of the sample served was determined and the glycemic index was determined using human subjects. The experimental results were then analysed statistically.

\section{Modification of arrowroot starch}

Native arrowroot (Maranta arundinacea) starch was set up to $20 \%$ moisture content by spraying water. The amount of water was determined by the following equilibrium wet mass. Starch reaching $20 \%$ moisture content (wb) was stirred and placed in high density polyethylene (HDPE) plastic pouch. The starch was set at room temperature for one night to homogenize moisture content. Wet starch was then treated with HMT by heating in an autoclave at a temperature of $121^{\circ} \mathrm{C}$ for 15 min. Furthermore, HMT-modified arrowroot starch was dried by a tray dryer for $2 \mathrm{~h}$ at $50^{\circ} \mathrm{C}$.

\section{Production of rice and cookies}

Rice (Oryza sativa) was cooked in a rice cooker (water to rice ratio of $3: 1$ ). Cooked rice was made on the same day as the day of testing. Cookies were made from wheat, native arrowroot starch, and HMT-modified arrowroot starch. The sample was prepared according to following formula: flour/starch/modified starch $(57.04 \%)$, fine sugar $(5.13 \%)$, palm sugar $(5.13 \%)$, margarine $(23.30 \%)$, skim milk powder $(4.24 \%)$, yolk $(4.97 \%)$, salt $(0.14 \%)$, baking soda $(0.02 \%)$, and vanilla $(0.02 \%)$. The cookies sample was then stored in the sealed plastic jar for further analysis.

\section{Proximate analysis}

Proximate analysis was conducted according to the Association of Official Agricultural Chemists (2012), including water content (925.10), ash (923.03), protein (960.52), fat (920.39), and carbohydrate (by difference).

\section{Glycemic carbohydrate determination}

The portion of reference and test foods must contain $50 \mathrm{~g}$ of glycemic carbohydrate, measured as total carbohydrate (by difference) minus dietary fiber. Dietary fiber and proximate composition were determined by AOAC (2012). Furthermore, based on dietary analysis, each subject had to consume $50 \mathrm{~g} \mathrm{AVCHO} \mathrm{(Available} \mathrm{Carbohydrate)} \mathrm{or} \mathrm{equal} \mathrm{as} \mathrm{one} \mathrm{portion} \mathrm{of} 146 \mathrm{~g}, 87 \mathrm{~g}, 74 \mathrm{~g}$, and 78 $\mathrm{g}$ for white rice, wheat cookies, NS-cookies, and HMT-cookies, respectively.

\section{The experiment for determining glycemic index}

Dextrose monohydrate/glucose (Qinhuangdao Lihua Starch CO, China) was used as the reference food. The portion consumed by subjects was AVCHO portion (total carbohydrate - Dietary Fibre (DF)). Volunteers were asked to fast overnight for 10-12 h. Glucose or samples containing $50 \mathrm{~g}$ of available carbohydrate (AVCHO) were consumed with $200 \mathrm{~mL}$ of water within $12 \mathrm{~min}$. Blood samples were obtained at 15, 30, 45, 60, 90, and 120 min consumption of samples, using One Touch Ultra Lifescan (Johnson and Johnson Company, USA). The tests were done with an interval time at least 3 days. GI values were calculated from Incremental Area under Curves (IAUC) of blood glucose curve of samples and compared with that of reference food, ignoring the area below the fasting concentration. It can be calculated by applying the trapezoid rule. When a blood glucose value falls below the baseline, only the area above the fasting level is included. The calculation of IAUC was using Microsoft Excel. 


$$
\mathrm{GI}=\frac{\text { IAUC of test sample } \times 100}{\text { IAUC of reference food }}
$$

\section{Data Analysis}

The GI obtained from several glucose trials used was statistically evaluated by one-way analysis of variance (ANOVA) followed by Duncan's multiple range test $(\mathrm{p}<0.05)$. The correlation between IAUC from both reference foods was determined by Pearson test $(p<0.05)$. Statistical software used was SPSS® version 20.

\section{RESULT AND DISCUSSION}

The mean of IAUC for 10 subjects was 4589 and the coefficient of variation (CV) was $24 \%$ (Table 1). The highest and lowest data for age were 36 and 21 y.o, while for BMI were 22 and 19 $\mathrm{kg} / \mathrm{m}^{2}$, respectively. We noticed that based on the Pearson correlation test there is no correlation between genders, age, BMI with average IAUC of glucose. The highest and lowest IAUC for women were 6848 and 3818 respectively, while for men were 5152 and 1240 respectively. After conducting statistical testing using the independent sample t-test, it was found that there was no significant difference in the mean IAUC between genders.

Table 1. Profile of subjects and the average coefficient of variance (CV) for individual glucose trials of Incremental Area Under Curve (IAUC)

\begin{tabular}{|c|c|c|c|c|c|c|c|c|c|}
\hline \multirow{2}{*}{ Subjects } & & \multirow{2}{*}{\begin{tabular}{|l|} 
Age \\
$($ y.o)
\end{tabular}} & \multirow{2}{*}{$\begin{array}{c}\text { BMI } \\
\left(\mathrm{kg} / \mathrm{m}^{2}\right)\end{array}$} & \multicolumn{3}{|c|}{ IAUC of glucose tests } & \multirow{2}{*}{$\begin{array}{c}\text { Mean IAUC } \\
(\mathrm{mmol.min} / \mathrm{L})\end{array}$} & \multirow{2}{*}{ SD } & \multirow{2}{*}{$\% \mathrm{CV}$} \\
\hline & & & & 1 & 2 & 3 & & & \\
\hline \multirow[t]{7}{*}{ Female } & 1 & 36 & 19 & 4980 & 5903 & 4605 & 5163 & 668 & 13 \\
\hline & 2 & 35 & 22 & 4283 & 6090 & 5430 & 5268 & 915 & 17 \\
\hline & 3 & 35 & 21 & 4050 & 2655 & 4748 & 3818 & 1065 & 28 \\
\hline & 4 & 25 & 22 & 7013 & 6180 & 7350 & 6848 & 602 & 9 \\
\hline & 5 & 24 & 22 & 3023 & 4515 & 4445 & 3994 & 842 & 21 \\
\hline & 6 & 23 & 19 & 7088 & 4403 & 5580 & 5690 & 1346 & 24 \\
\hline & 7 & 35 & 20 & 4500 & 5526 & 3090 & 4372 & 1223 & 28 \\
\hline \multirow[t]{3}{*}{ Male } & 8 & 24 & 21 & 5270 & 5243 & 4943 & 5152 & 182 & 4 \\
\hline & 9 & 21 & 21 & 3910 & 5419 & 3713 & 4347 & 933 & 21 \\
\hline & 10 & 21 & 21 & 2277 & 638 & 804 & 1240 & 902 & 73 \\
\hline Mean & - & $28 \pm 6$ & $21 \pm 1$ & - & - & - & 4589 & 868 & 24 \\
\hline
\end{tabular}

$C V=($ s.d./mean $) \times 100$

The comparison of GI done was based on three aspects according to the protocol of FAO and BPOM, including how many subjects, glucose trials (reference food trials), and sampling points, showed in Table 2.

Table 2. Comparison of Glycemic Index (GI) recommendation methods by BPOM and FAO

\begin{tabular}{lcc}
\hline Aspects & FAO $(\mathbf{1 9 9 8})$ & BPOM (2011) \\
\hline Subjects enrolled & $>6$ & 10 \\
Fasting time & $10-12 \mathrm{~h}$ & $10 \mathrm{~h}$ \\
AVCHO consumed & $50 \mathrm{~g}$ & $50 \mathrm{~g}$ \\
Reference food type & Glucose or white bread & Glucose \\
Reference food trials & At least 3 times & No specific recommendation \\
Blood sampling points (min) & $0,15,30,45,60,90,120$ (7 points) & $0,30,60,90,120$ (5 points) \\
GI calculation & IAUC & IAUC \\
\hline
\end{tabular}

BPOM and FAO recommend a minimum number of subjects on the GI, which is 10 and more than 6, respectively. Ten subjects were used in this research, so to follow BPOM recommendation, we used the entire subject even though there is actually one outlier which showed CV up to $73 \%$. While 
following FAO recommendation, we exclude some of the data which were having the high CVs. Both of the methods did not suggest how to handle the outliers. To deal with outliers, it would be better if more subjects were used than recommended in FAO. Although there was outlier in this research, the results showed that the number of subjects enrolled (10 or 7$)$ not altered the CV.

The reference food used in this research was dextrose monohydrate/glucose. From three glucose trials, seven basis reference curves were obtained to be used in GI calculation. Single glucose trial means that GI value is calculated by one glucose test, while duplicate glucose trials mean that GI value is calculated by the mean of two glucose tests. Similarly, the triplicate glucose trials are calculated by the mean of three glucose tests. The results showed no significant difference in GI of all samples based on different glucose curves. GI value was obtained from the ratio of two independent variable values. As one of the variabilities of the values increases, the mean also increases, even if the original values are normally distributed. Thus, more reference tests led to a reduction of variability. Even though triplicate glucose trials gave lower CV to the mean of GI, it was not different from duplicate or single glucose trial. As reported by Wolever et al., (2003), the statistical results (mean, standard deviation) in one reference food trial for GI calculation seemed to be higher than those in three reference food trials. $\mathrm{CV}$ of the reference food more contributed to the results, compared to CV of the test foods, since it is used to calculate the GI value of every test food in the series. Besides, GI obtained from the mean of triplicate glucose trials had a lower CV than that from single or duplicate glucose trials.

Table 3. Glycemic Index (GI) value of the samples based on different glucose trials

\begin{tabular}{|c|c|c|c|c|c|c|c|c|c|c|}
\hline \multirow{3}{*}{\multicolumn{2}{|c|}{ Glucose curves }} & \multicolumn{8}{|c|}{ GI values } & \multirow{3}{*}{$\begin{array}{c}\text { Mean of } \\
\% \mathrm{CV}\end{array}$} \\
\hline & & \multicolumn{2}{|c|}{ White rice } & \multicolumn{2}{|c|}{ Wheat cookies } & \multicolumn{2}{|c|}{ NS-cookies } & \multicolumn{2}{|c|}{ HMT-cookies } & \\
\hline & & $\begin{array}{l}\text { Mean } \\
\pm \text { s.d. }\end{array}$ & $\% \mathrm{CV}$ & $\begin{array}{c}\text { Mean } \pm \\
\text { s.d. }\end{array}$ & $\% \mathrm{CV}$ & $\begin{array}{l}\text { Mean } \\
\pm \text { s.d. }\end{array}$ & $\% \mathrm{CV}$ & $\begin{array}{c}\text { Mean } \pm s . \\
\text { d. }\end{array}$ & $\% \mathrm{CV}$ & \\
\hline \multirow{4}{*}{$\begin{array}{l}\text { Single } \\
\text { glucose } \\
\text { trial }\end{array}$} & 1 & $\underset{\mathrm{a}}{71 \pm 21}$ & 29 & $58 \pm 26^{\mathrm{a}}$ & 45 & $38 \pm 21^{\mathrm{a}}$ & 56 & $37 \pm 14^{\mathrm{a}}$ & 39 & $42^{\mathrm{a}}$ \\
\hline & 2 & $\underset{\mathrm{a}}{83 \pm 45}$ & 54 & $67 \pm 44^{\mathrm{a}}$ & 66 & $42 \pm 21^{\mathrm{a}}$ & 51 & $44 \pm 29^{a}$ & 66 & $59^{a}$ \\
\hline & 3 & $\frac{80 \pm 29}{a}$ & 36 & $67 \pm 39^{a}$ & 58 & $41 \pm 16^{\mathrm{a}}$ & 39 & $44 \pm 26^{\mathrm{a}}$ & 59 & $48^{\mathrm{a}}$ \\
\hline & $\overline{\mathrm{x}}$ & $78 \pm 32$ & 40 & $64 \pm 36$ & 56 & $40 \pm 19$ & 49 & $42 \pm 23$ & 55 & 50 \\
\hline \multirow{4}{*}{$\begin{array}{l}\text { Mean of } \\
\text { duplicat } \\
\text { e } \\
\text { glucose } \\
\text { trials }\end{array}$} & $1 \& 2$ & $\underset{\mathrm{a}}{72 \pm 17}$ & 23 & $58 \pm 22^{\mathrm{a}}$ & 38 & $37 \pm 15^{\mathrm{a}}$ & 40 & $37 \pm 13^{\mathrm{a}}$ & 35 & $34^{\mathrm{a}}$ \\
\hline & $1 \& 3$ & $73 \pm 14$ & 19 & $60 \pm 26^{a}$ & 43 & $38 \pm 15^{\mathrm{a}}$ & 39 & $39 \pm 17^{\mathrm{a}}$ & 43 & $36^{\mathrm{a}}$ \\
\hline & $2 \& 3$ & $\underset{\mathrm{a}}{74 \pm 37}$ & 46 & $60 \pm 41^{\mathrm{a}}$ & 61 & $41 \pm 19^{\mathrm{a}}$ & 46 & $44 \pm 27^{\mathrm{a}}$ & 62 & $54^{\mathrm{a}}$ \\
\hline & $\overline{\mathrm{x}}$ & $73 \pm 16$ & 29 & $59 \pm 30$ & 47 & $39 \pm 16$ & 42 & $40 \pm 19$ & 47 & 41 \\
\hline $\begin{array}{l}\text { Mean of } \\
\text { triplicat } \\
\text { e } \\
\text { glucose } \\
\text { trials }\end{array}$ & $\begin{array}{c}1,2 \& \\
3\end{array}$ & $\underset{\mathrm{a}}{74 \pm 16}$ & 22 & $60 \pm 24^{\mathrm{a}}$ & 41 & $38 \pm 14^{\mathrm{a}}$ & 36 & $39 \pm 16^{\mathrm{a}}$ & 41 & $35^{\mathrm{a}}$ \\
\hline
\end{tabular}

Table 1 shows that GI of several glucose trials ranged from 71 to 83,58 to 67,38 to 42 , and 37 to 44 in white rice, wheat cookies, NS cookies, and HMT-cookies. However, these values did not differ significantly ( $n=10, p>0.05)$. The use of seven blood glucose sampling points gave larger IAUC than five sampling points in one sample subject consuming HMT-cookies. The IAUC of test food was increased in correlation with reference food resulting in a constant ratio. Even though the mean GI with seven blood glucose sampling points gave a slightly higher value than five sampling points, the 
mean GI of both methods showed no significant difference $(n=10, p>0.05)$ in all of the samples (Table 4).

Table 4. The Glycemic Index (GI) value of the samples based on blood glucose sampling points

\begin{tabular}{|c|c|c|c|c|c|}
\hline \multirow{3}{*}{ Sample } & \multicolumn{4}{|c|}{ GI } & \multirow{3}{*}{$\%$ difference } \\
\hline & \multicolumn{2}{|c|}{ BPOM protocols ( 5 points) } & \multicolumn{2}{|c|}{ FAO protocols ( 7 points) } & \\
\hline & Mean \pm s.d & $\% \mathrm{CV}$ & Mean \pm s.d & $\% \mathrm{CV}$ & \\
\hline White rice & $70 \pm 18^{\mathrm{a}}$ & 26 & $74 \pm 16^{\mathrm{a}}$ & 22 & 5,41 \\
\hline Wheat cookies & $60 \pm 25^{\mathrm{a}}$ & 42 & $60 \pm 25^{\mathrm{a}}$ & 42 & 0 \\
\hline NS- cookies & $36 \pm 13^{\mathrm{a}}$ & 36 & $38 \pm 14^{\mathrm{a}}$ & 37 & 5,26 \\
\hline HMT-cookies & $38 \pm 18^{\mathrm{a}}$ & 47 & $39 \pm 16^{\mathrm{a}}$ & 41 & 2,56 \\
\hline
\end{tabular}

The blood withdrawal was performed seven times, at 15-minute intervals for the first hour and 30-minute intervals for the second hour; this is noteworthy that the intervals affect the area under curve. Even though the average GI obtained from seven blood glucose sampling points were slightly higher than that from five sampling points, the average GI of both methods showed no significant difference $(n=10, p>0.05)$ in all of the samples. This is in accordance with Chung et al., (2009), finding that peak rise in 10 -min intervals was $4 \%$ greater than that in 15 -min intervals $(\mathrm{p}<0.001)$; yet, blood sampling interval did not significantly affect IAUC.

Table 5 shows that different methodologies can result in different GI values, but shows no significant difference $(\mathrm{p}>0.05)$. Range of GI for rice, wheat cookies, NS-cookies, HMT-cookies were $68-77 ; 55-60 ; 35-43 ; 35-41$, respectively. GI based on BPOM methodology (10 subjects with 5 sampling points) have CV ranged $37-49 \%$, while GI based on FAO methodology (7 subjects with triplicate glucose trials and 7 sampling points) were $33 \%$ and $35 \%$. Using 7 subjects with triplicate glucose trials and 7 sampling points gave the lowest CV. The same CV was obtained from using 7 subjects with duplicate glucose trials and 7 sampling points, which was giving lower cost. The use of 7 subjects with duplicate glucose trials and 7 sampling points in both groups gave the same lowest $\mathrm{CV}$. The coefficient variance shows the extent of variability in the relation to the mean of population; the lower CV means the lower variability on the results. The number of subjects (10 or 7) did not give a difference in $\mathrm{CV}$, while reference food trials showed a difference in the CV. Single reference food trial gave the highest $\mathrm{CV}$ in comparison with duplicate and triplicate trials, indicating that GI value with low CV could be obtained by performing at least two replications of reference trial. Blood sampling points also affected $\mathrm{CV}$ of the GI; in this case, 7 sampling points gave lower CV than 5 sampling points, even though not significantly differ.

As previously discussed, the variation in glucose trials and sampling intervals had no significant difference in GI value single, observed in all reference trials and sampling points. These points are also recognized by GI determination method prescribed by BPOM and FAO. GI test recommendation is included in the Joint FAO/WHO Expert Consultation on Carbohydrate in Human Nutrition held in Rome, 1997 (FAO, 1998), while in Indonesia, GI test recommendation is included in supervision claims in labeling and advertising of processed food No.HK.03.1.23.12.11.09909 2011 released by BPOM. Thus, it is interesting to calculate GI based on both recommended methods. 
Table 5. Coefficients variance (CV) of Glycemic Index (GI) based on the combination of three aspects (amount of subjects, glucose trials, and sampling points) according to the protocol of FAO and BPO

\begin{tabular}{|c|c|c|c|c|c|c|c|c|c|c|c|c|c|c|c|c|}
\hline \multirow{2}{*}{$\begin{array}{l}\text { Subj } \\
\text { ect }\end{array}$} & \multirow{2}{*}{$\begin{array}{c}\text { Glucose } \\
\text { trials }\end{array}$} & \multirow{2}{*}{$\begin{array}{c}\text { Samp } \\
\text { ling } \\
\text { Point } \\
\text { S }\end{array}$} & \multirow{2}{*}{$\begin{array}{l}\text { Prot } \\
\text { ocols }\end{array}$} & \multicolumn{3}{|c|}{ Rice } & \multicolumn{3}{|c|}{ Wheat cookies } & \multicolumn{3}{|c|}{ NS cookies } & \multicolumn{3}{|c|}{ HMT cookies } & \multirow{2}{*}{$\begin{array}{l}\text { Me } \\
\text { an } \\
\text { CV }\end{array}$} \\
\hline & & & & GI & SD & CV & GI & $\begin{array}{l}\text { S } \\
\text { D }\end{array}$ & $\mathbf{C V}$ & GI & SD & CV & GI & SD & $\mathbf{C V}$ & \\
\hline \multirow{6}{*}{10} & \multirow[t]{2}{*}{ Single } & 5 & \multirow[t]{6}{*}{$\begin{array}{c}\mathrm{BPO} \\
\mathrm{M}\end{array}$} & $\begin{array}{c}68 \\
\mathrm{a}\end{array}$ & 24 & 35 & $58^{a}$ & 28 & 48 & $36^{\mathrm{a}}$ & 22 & 62 & $36^{\mathrm{a}}$ & 19 & 53 & $49^{\mathrm{a}}$ \\
\hline & & 7 & & 71 & 21 & 29 & $58^{\mathrm{a}}$ & 26 & 45 & $38^{\mathrm{a}}$ & 21 & 56 & $37^{\mathrm{a}}$ & 14 & 39 & $42^{\mathrm{a}}$ \\
\hline & \multirow[t]{2}{*}{$\begin{array}{l}\text { Mean of } \\
\text { duplicate }\end{array}$} & 5 & & 68 & 18 & 27 & $57^{\mathrm{a}}$ & 21 & 36 & $35^{\mathrm{a}}$ & 15 & 42 & $36^{\mathrm{a}}$ & 15 & 42 & $37^{\mathrm{a}}$ \\
\hline & & 7 & & $\begin{array}{c}72 \\
\mathrm{a}\end{array}$ & 17 & 23 & $58^{\mathrm{a}}$ & 22 & 38 & $37^{\mathrm{a}}$ & 15 & 40 & $38^{\mathrm{a}}$ & 13 & 36 & $34^{\mathrm{a}}$ \\
\hline & \multirow[t]{2}{*}{$\begin{array}{l}\text { Mean of } \\
\text { triplicate }\end{array}$} & 5 & & $\begin{array}{c}70 \\
\mathrm{a}\end{array}$ & 18 & 26 & $60^{\mathrm{a}}$ & 25 & 42 & $36^{\mathrm{a}}$ & 13 & 37 & $38^{\mathrm{a}}$ & 18 & 47 & $38^{\mathrm{a}}$ \\
\hline & & 7 & & $\begin{array}{c}74 \\
\mathrm{a} \\
\end{array}$ & 16 & 22 & $60^{\mathrm{a}}$ & 25 & 41 & $38^{\mathrm{a}}$ & 14 & 36 & $39^{\mathrm{a}}$ & 16 & 41 & $35^{\mathrm{a}}$ \\
\hline \multirow{6}{*}{$\begin{array}{c}7 \\
\text { (Gro } \\
\text { up 1) }\end{array}$} & \multirow[t]{2}{*}{ Single } & 5 & \multirow[t]{6}{*}{ FAO } & $\begin{array}{c}73 \\
\mathrm{a}\end{array}$ & 26 & 36 & $60^{\mathrm{a}}$ & 30 & 51 & $39^{\mathrm{a}}$ & 26 & 66 & $41^{\mathrm{a}}$ & 21 & 51 & $51^{\mathrm{a}}$ \\
\hline & & 7 & & $\begin{array}{c}76 \\
\mathrm{a}\end{array}$ & 22 & 29 & $59^{a}$ & 29 & 50 & $41^{\mathrm{a}}$ & 24 & 60 & $40^{\mathrm{a}}$ & 15 & 38 & $44^{\mathrm{a}}$ \\
\hline & \multirow[t]{2}{*}{$\begin{array}{l}\text { Mean of } \\
\text { duplicate }\end{array}$} & 5 & & $\begin{array}{c}70 \\
\mathrm{a}\end{array}$ & 19 & 26 & $56^{\mathrm{a}}$ & 20 & 37 & $37^{\mathrm{a}}$ & 17 & 47 & $38^{\mathrm{a}}$ & 14 & 37 & $37^{\mathrm{a}}$ \\
\hline & & 7 & & $\begin{array}{c}75 \\
\mathrm{a}\end{array}$ & 16 & 21 & $57^{\mathrm{a}}$ & 22 & 38 & $39^{\mathrm{a}}$ & 17 & 44 & $40^{\mathrm{a}}$ & 12 & 30 & $33^{\mathrm{a}}$ \\
\hline & \multirow[t]{2}{*}{$\begin{array}{l}\text { Mean of } \\
\text { triplicate }\end{array}$} & 5 & & $\begin{array}{c}69 \\
a\end{array}$ & 14 & 20 & $56^{\mathrm{a}}$ & 23 & 41 & $36^{\mathrm{a}}$ & 16 & 43 & $39^{\mathrm{a}}$ & 16 & 41 & $36^{\mathrm{a}}$ \\
\hline & & 7 & & $\begin{array}{c}74 \\
\mathrm{a}\end{array}$ & 12 & 17 & $57^{\mathrm{a}}$ & 23 & 40 & $38^{a}$ & 15 & 40 & $40^{\mathrm{a}}$ & 14 & 36 & $33^{\mathrm{a}}$ \\
\hline \multirow{6}{*}{$\begin{array}{c}7 \\
\text { (Gro } \\
\text { up 2) }\end{array}$} & \multirow[t]{2}{*}{ Single } & 5 & \multirow[t]{7}{*}{ FAO } & $\begin{array}{c}76 \\
\mathrm{a}\end{array}$ & 24 & 32 & $57^{\mathrm{a}}$ & 27 & 48 & $42^{\mathrm{a}}$ & 25 & 60 & $37^{\mathrm{a}}$ & 20 & 55 & $48^{\mathrm{a}}$ \\
\hline & & 7 & & 76 & 23 & 30 & $55^{\mathrm{a}}$ & 27 & 50 & $43^{a}$ & 24 & 56 & $36^{\mathrm{a}}$ & 13 & 36 & $43^{\mathrm{a}}$ \\
\hline & \multirow[t]{2}{*}{$\begin{array}{l}\text { Mean of } \\
\text { duplicate }\end{array}$} & 5 & & $\begin{array}{c}74 \\
\mathrm{a}\end{array}$ & 17 & 23 & $57^{a}$ & 22 & 40 & $39^{\mathrm{a}}$ & 15 & 38 & $35^{\mathrm{a}}$ & 15 & 42 & $36^{\mathrm{a}}$ \\
\hline & & 7 & & 77 & 16 & 21 & $56^{\mathrm{a}}$ & 24 & 43 & $41^{\mathrm{a}}$ & 15 & 37 & $37^{\mathrm{a}}$ & 12 & 32 & $33^{\mathrm{a}}$ \\
\hline & \multirow[t]{2}{*}{$\begin{array}{l}\text { Mean of } \\
\text { triplicate }\end{array}$} & 5 & & $\begin{array}{c}75 \\
\mathrm{a}\end{array}$ & 19 & 25 & $58^{\mathrm{a}}$ & 26 & 45 & $39^{\mathrm{a}}$ & 14 & 36 & $36^{\mathrm{a}}$ & 17 & 47 & $38^{\mathrm{a}}$ \\
\hline & & 7 & & $\underset{\mathrm{a}}{77}$ & 17 & 22 & $56^{a}$ & 26 & 46 & $41^{\mathrm{a}}$ & 15 & 36 & $37^{\mathrm{a}}$ & 14 & 37 & $35^{\mathrm{a}}$ \\
\hline & \multicolumn{2}{|c|}{ Grand Mean } & & 73 & 19 & 26 & 57 & 25 & 43 & 38 & 18 & 46 & 38 & 15 & 41 & 39 \\
\hline
\end{tabular}

All values are averaged ( $n=10$ for 10 subjects, $n=7$ for 7 subjects, $n=4$ for mean $C V, p>0,05$, Anova). Glucose trials, single (1st glucose trials); mean of duplicate (mean of the 1st \& 2nd glucose trials); mean of triplicate (mean of the 1st, 2nd, and 3rd glucose trials). Blood sampling points, 5 (0, 30, 60, 90, 12 min); 7 (0, 15, 30, 45, 60, 90, $120 \mathrm{~min})$. Means sharing the same superscript are not significantly different from each other $(P>0.05)$.

Using 7 subjects with triplicate glucose trials and 7 sampling points gave the lowest $\mathrm{CV}$. The same CV was obtained from using 7 subjects with duplicate glucose trials and 7 sampling points, resulting in a lower cost. In addition, GI determination using 7 subjects with duplicate glucose trials 
and 7 sampling points in both groups gave the same lowest $\mathrm{CV}$. The importance of CV needs to consider since it shows the extent of variability in relation to the mean of a population; the lower $\mathrm{CV}$ means the lower variability of the results. Subjects enrolled (10 or 7) unaltered CV, while reference food trials remarkably altered CV. Single reference food trials resulted in the highest CV among duplicate and triplicate trials, indicating that reference trials should be carried out at least two times to get GI with low CV. Blood sampling points also affected CV of the GI, in which lower CV was found in 7 sampling points, compared to 5 sampling points, though not differ significantly. The tworecommendation methods results are not significantly different can be caused by the smaller number of samples taken in the BPOM recommendation ( 5 sampling points) compensated by a larger number of subjects (10 subjects). This is in line with the FAO recommendation, which takes more samples (7 sampling points) with fewer subjects ( 7 subjects). The results showed that both recommendation methods were also placing the food in the same GI category. It will be very useful in future research, if the two recommendations method (BPOM and FAO) were compared with International Organization for Standardization recommendation (International Organization for Standardization, 2010), which recommend minimum of 10 subjects, at least two reference food trials, and seven blood sampling points.

\section{CONCLUSION}

We concluded that GI determination by using seven subjects with duplicate glucose trials and seven blood sampling points resulted in the lowest $\mathrm{CV}$, which was more statistically satisfied. Therefore, it was recommended to perform at least twice reference food trials, using at least seven subjects and seven blood sampling points.

\section{ACKNOWLEDGEMENT}

We are grateful for the research funding by DIKTI through Penelitian Unggulan Dasar program 2014 and Laboratory of Food Analysis (LDITP) IPB.

\section{REFERENCES}

Association of Official Agricultural Chemists. (2012). Official methods of analysis of AOAC international. Volume II. $19^{\text {th }}$ edition. AOAC, Maryland

Barakatun Nisak, M. Y., Ruzita, A. T., Norimah, A. K., Nor Azmi, K., \& Fatimah, A. (2009). Acute effect of low and high glycemic index meals on post-prandial glycemia and insulin responses in patients with type 2 diabetes mellitus. Malaysian Journal of Medicine and Health Sciences, 5(1), $11-20$

Bouché, C., Rizkalla, S. W., Luo, J., Vidal, H., Veronese, A., Facher, N., Fouquet, C., Lang, V., \& Slama, G. (2002). Five-week, low-glycemic index diet decreases total fat mass and improves plasma lipid profile in moderately overweight nondiabetic men. Diabetes Care, 25(5), 822-828. https://doi.org/10.2337/diacare.25.5.822

BPOM. (2011). Metode standar penentuan indeks glikemik pangan. Lampiran VI Peraturan Kepala Badan Pengawas Obat dan Makanan Nomor HK. 03.1.23.12.11.09909 Tahun 2011 tentang pengawasan klaim dalam label dan iklan pangan olahan. BPOM, Jakarta.

Chung, H. J., Liu, Q., \& Hoover, R. (2009). Impact of annealing and heat-moisture treatment on rapidly digestible, slowly digestible and resistant starch levels in native and gelatinized corn, pea and lentil starches. Carbohydrate Polymers, 75(3), 436-447. https://doi.org/10.1016/j.carbpol.2008.08.006

Faridah, D. N. (2005). Sifat fisiko kimia tepung Suweg (Amorphophallus campanulatus B1.) dan indeks glisemiknya. In Teknologi dan industri pangan (Vol. 16, Issue 3, pp. 254-259)

FAO/WHO. (1998). Carbohydrates in Human Nutrition. FAO Food and Nutrition Paper 66. FAO, Rome.

International Organization for Standardization (2010).International Standard 26642:2010, 2010 
(Determination of the glycemic index (GI) and recommendation for food classification), p.18.

Liu, S., Willett, W. C., Stampfer, M. J., Hu, F. B., Franz, M., Sampson, L., Hennekens, C. H., \& Manson, J. A. E. (2000). A prospective study of dietary glycemic load, carbohydrate intake, and risk of coronary heart disease in US women. American Journal of Clinical Nutrition, 71(6), 1455-1461. https://doi.org/10.1093/ajcn/71.6.1455

Gilbertson, H.R., Brand-Miller, J.C., Thorburn, A.W., Evans, S., Chondros, P. \& Werther, G.A. (2001). The effect of flexible low glycemic diets on glycemic control in children with type 1 diabetes. Diabetes Care, 24(7),1137-1147

Marsono, Y. (2002). Indeks glikemik umbi-umbian. In agriTECH (Vol. 22, Issue 1, pp. 13-16)

Mir, J. A., Srikaeo, K., \& García, J. (2013). Effects of amylose and resistant starch on starch digestibility of rice flours and starches. International Food Research Journal, 20(3), 1329-1335

Moses, R. G., Barker, M., Winter, M., Petocz, P., \& Brand-Miller, J. C. (2009). Can a low-glycemic index diet reduce the need for insulin in gestational diabetes mellitus? A randomized trial. Diabetes Care, 32(6), 996-1000. https://doi.org/10.2337/dc09-0007

Odenigbo, A., Rahimi, J., Ngadi, M., Amer, S., \& Mustafa, A. (2012). Starch digestibility and predicted glycemic index of fried sweet potato cultivars. Functional Foods in Health and Disease, 2(7), 280-289. https://doi.org/10.31989/ffhd.v2i7.83

Stevenson, E. J., Williams, C., Mash, L. E., Phillips, B., \& Nute, M. L. (2006). Influence of highcarbohydrate mixed meals with different glycemic indexes on substrate utilization during subsequent exercise in women. American Journal of Clinical Nutrition, 84(2), 354-360. https://doi.org/10.1093/ajcn/84.2.354

Syahbanu, F. (2015). Modifikasi pati garut (Maranta arundinaceae L.) dengan hidrolisis asam, siklus autoclaving-cooling, dan heat-moisture treatment (HMT) untuk menghasilkan pati resisten tipe III (RS3). Thesis. Food Science and Technology, Bogor Agricultural University, Bogor

Wolever, T. M.S., Jenkins, D. J. A., Jenkins, A. L., \& Josse, R. G. (1991). The glycemic index: Methodology and clinical implications. American Journal of Clinical Nutrition, 54(5), 846-854. https://doi.org/10.1093/ajcn/54.5.846

Wolever, T. M.S., Jenkins, D. J. A., Vuksan, V., Jenkins, A. L., Wong, G. S., \& Josse, R. G. (1992). Beneficial effect of low-glycemic index diet in overweight NIDDM subjects. Diabetes Care, 15(4), 562-564. https://doi.org/10.2337/diacare.15.4.562

Wolever, Thomas M.S., Vorster, H. H., Björck, I., Brand-Miller, J., Brighenti, F., Mann, J. I., Ramdath, D. D., Granfeldt, Y., Holt, S., Perry, T. L., Venter, C., \& Wu, X. (2003). Determination of the glycaemic index of foods: Interlaboratory study. European Journal of Clinical Nutrition, 57(3), 475-482. https://doi.org/10.1038/sj.ejcn.1601551 
